\title{
Comparative study of special honey products and herbhoneys
}

\author{
Anna Novák - Loránd Alexa - Béla Kovács - Nikolett Czipa \\ University of Debrecen, Faculty of Agricultural and Food Science and Environmental Management, \\ Institute of Food Science, Debrecen \\ novak.anna@agr.unideb.hu
}

\begin{abstract}
SUMMARY
Honey has a positive effect on human body due to its high content of biologically active substances (e.g. monosaccharides, vitamins, enzymes, amino acids, polyphenolic compounds). The properties of honey depend on its botanical origin due to the bioactive plant components, mainly secondary metabolites that are included in honey made by bees from nectar. Herbally infused honeys are delicious products that combine the therapeutic action of herbs and honey. Additionally, herbs can provide nutrient fortified syrup for honey bees and protect them against diseases and other ecological threats.

The aim of this study was to define the physicochemical properties of multifloral honey, herb enriched natural honey and herbhoney samples. We measured the moisture content, pH value, electrical conductivity and proline content. Although great diversity was observed in the basic properties of the examined products. In our study, we found that the electrical conductivity shows the significant differ between the groups. All the samples, including the herbhoneys passes the quality standards of honeys.
\end{abstract}

Keywords: honey, herb enriched honey, herbhoney, physicochemical properties

\section{INTRODUCTION}

Since the beginning of the time, honey always had been an important nutriment for humanity, as the only available sweetener. Beside its pleasant taste, it is also an excellent source of carbohydrates (Crane 1983).

According to Codex Alimentarius Hungaricus, honey is a natural sweet substance produced by honey bees from nectar or honeydew. Beside the great number of mellifluous plants, there are lot of herbs that do not serve as nectar sources. However, these plants are very popular, because they have beneficial impact to human body (Nagy et al. 2014).

Therefore a new type of bee product, herbhoney has been developed. During the production bees are fed by sugar-based food containing herbals, this way the medical benefits of honey and herbals may prevail at the same time (Isadorov et al. 2015, Lukasiewitcz et al. 2015). According to the Codex Alimentarius, as it was mentioned above, herbhoneys cannot be called honey due to their method of production, involves feeding sugar syrup to bees. Therefore, in Hungary herbhoneys can be found under the fantasy name „Többmintméz”. It literally means „Morethanhoney”.

The chemical composition of herbhoneys is similar to honey's parameters, particularly the moisture, carbohydrate, organic acid and hydroximethylfurfural contents, conductivity and diastase number. These parameters generally met the quality criteria of honeys (Juszczak et al. 2009, Socha et al. 2009, Jamróz et al. 2014). On the other hand, herbhonyes have higher micro- and macro element and $\mathrm{C}$ vitamin content as described by Juszczak et al. in 2009. Herbhoney also contains other components with antioxidant properties, such as phenolic acids and flavonoids (Socha et al. 2009). In some cases, herbhoneys show higher antimicrobial activity than natural honeys (Lukasiewitcz et al. 2015).
The other method combines the positive effect of herbs and honeys due to the addition of the dried plants to the natural nectar honey. This type of honey has similar nutritional values as natural honey; however the addition of herbs results in new health promoting properties. Dry herbs are distributed in honey, and it assumed that the bioactive components are transferred to the honey (Dzugan et al. 2017). This type of product become more and more popular and many beekeepers developed their products on this way (Szalay 2009). However, there are just a few researches about these products' quality parameters.

The herb enriched honeys have different effects on the human body, depends on the plant sources (Dzugan et al. 2017). For example, the aloe honey regulates digestion, while berries protect cardio vascular diseases. Herb enriched honey products have a wide application in pharmacy and medicine both as drug components, prophylactic agents and dietary supplements (Downey et al. 2005).

The aim of this study was to determine the physicochemical properties of herb enriched honey products. As a control, multifloral honey samples were used.

\section{MATERIAL AND METHODES}

Samples were divided into three groups: 1 . multifloral honey $(n=20), 2$. herb enriched natural honey $(n=21), 3$. herbhoney $(n=24)$.

Herb enriched honey made such a way that dried herbs have been distributed in the entire volume of honey, and filtered. Samples were the followings: blueberries (Vaccinium vitis-idaea), buckthorn (Hippophae), cinnamon (Cinnamomi cortex), cranberry (Vaccinium oxyciocco), elderberry (Sambucus), elderflower (Sambucus), eucalyptus (Eucalyptus), ginger (Zingiber officinale), hibiscus-rosehipps (HibiscusRosa canina, lavender (Lavandula spica), lemongrass 
(Melissa officinalis), mint (Mentha spicata), spearhead (Plantago lanceolate), winter spice.

However, third group of samples, herbhoneys are made by feeding bees with sugar syrup which contain herd extract. The samples were the followings: aloe vera (Aloe vera), buckthorn (Hippophae), buckthornragweed (Hippophae- Ambrosia artemisiifolia), chamomile (Matricaria chamomilla), cinnamon (Cinnamomi corte), dill (Anethum graveolens), elderberry (Sambucus), garlic-lemon (Allium sativumCitrus $\times$ limon), hot paprika (Capsicum frutescens), nettle (Urtica dioica), peppermint (Mentha $\times$ piperita), ragweed (Ambrosia artemisiifolia), rose hipps- niesplik (Rosa canina- Mespilus canescens), rose hips (Rosa canina). All samples were stored at 20 ${ }^{\circ} \mathrm{C}$ until the analysis.

Examined parameters were: moisture content, $\mathrm{pH}$ value, electrical conductivity, proline content. The results were compared to limit values of Codex Alimentarius Hungaricus, and the other reports in the literature.

The moisture contents were measured by refractometric method with digital refractometer (Medline DIGIT 5890 ATC Honey Pocket refractometer, United Kingdom). The $\mathrm{pH}$ values were determined by (the using a) digital $\mathrm{pH}$ meter (FiveEasyTM FE20, Mettler-Toledo AG, Switzerland), as described in MSZ 6943/3-80. Electrical conductivity was determined by the method of Bodgdanov (1997), using digital conductivity meter (FiveEasyTM FE30, Mettler-Toledo AG, Switzerland).

Measurement of proline content was performed according to the method of Meda et al. (2005) with a spectrophotometer (Evolution 300 LC, Thermo
Electron Corporation, England) at $510 \mathrm{~nm}$. Results are given in $\mathrm{mg} \mathrm{kg}^{-1}$.

All analytical analyses were carried out in triplicate. Data are described by using general terms (mean, standard deviation, minimum and maximum values). The significant differences $(p<0.05)$ were determined among the studied honey products using one-way analysis of variance (ANOVA) with Dunnett's test. SPSS for Windows (version 13; SPSS Inc. Chicago, Illinois, USA) was used for all calculations.

\section{RESULTS AND DISCUSSION}

The results for the basic parameters of the studied honey products are summarized in Table 1 .

In natural honeys, moisture content is an indicator of their degree of maturity and of storage method. European honeys as a rule do not exceed the maximum allowed water content of $20 \%$ (Downey et al. 2005). The moisture contents of multifloral honeys ranged from $17.5 \pm 0.1 \%$ to $21.6 \pm 0.1 \%$. In case of herb enriched nectar honey it was between $15.9 \pm 0.1 \%$ $21 \pm 0.1 \%$. Whereas the herbhoneys' moisture content was between $15.9 \pm 0.1 \%$ and $21.6 \pm 0.1 \%$. The average moisture content of honeys was $18.9 \pm 1.1 \%$, the herb enriched honeys was $18.4 \pm 1.4 \%$ and the herbhoneys was $17.0 \pm 0.7 \%$. According to the result of the statistical analysis, it was concluded, that in case of the moisture content of honeys and herb enriched honeys there was no significant difference, however the herbhoneys showed differences from the two other groups. Our results correspond to this requirement. The moisture content of our samples was supported by data in literature (Juszczak et al. 2009, Czipa 2010).

Table 1

Physicochemical parameters of studied samples

\begin{tabular}{|c|c|c|c|c|c|}
\hline Sample & Statistic & $\begin{array}{c}\text { Moisture content } \\
(\%)\end{array}$ & $\mathrm{pH}$ value & $\begin{array}{c}\text { Electrical } \\
\text { conductivity } \\
\left(\mu \mathrm{S} \mathrm{cm}^{-1}\right)\end{array}$ & $\begin{array}{l}\text { Proline content } \\
\quad\left(\mathrm{mg} \mathrm{kg}^{-1}\right)\end{array}$ \\
\hline \multirow{2}{*}{ 1. multifloral honey $(n=20)$} & Mean \pm SD & $18.9 \pm 1.1 \mathrm{a}$ & $3.56 \pm 0.2 \mathrm{a}$ & $278 \pm 106 a$ & $601 \pm 152 \mathrm{a}$ \\
\hline & Range & $17.5-21.6$ & $3.23-4.12$ & $138-585$ & $369-971$ \\
\hline \multirow{2}{*}{ 2. herb enriched nectar honey $(n=21)$} & Mean \pm SD & $18.4 \pm 1.4 \mathrm{a}$ & $3.69 \pm 0.4 \mathrm{a}$ & $420 \pm 225 b$ & $640 \pm 272 a$ \\
\hline & Range & $15.9-21.0$ & $2.91-4.27$ & $168-870$ & $250-1187$ \\
\hline \multirow{2}{*}{ 3. herbhoney $(n=24)$} & Mean \pm SD & $17.0 \pm 0.7 \mathrm{~b}$ & $4.07 \pm 0.23 b$ & $643 \pm 127 c$ & $546 \pm 130 \mathrm{a}$ \\
\hline & Range & $15.9-21.6$ & $3.76-4.62$ & $448-963$ & $368-785$ \\
\hline Quality standard & & $<20$ & - & $<800$ & $<180$ \\
\hline
\end{tabular}

Note: data with the same letter in the same columns is not significantly different at the significant level of 0.05 .

The $\mathrm{pH}$ value of honey is usually between 3 and 5. Lower $\mathrm{pH}$ is resulted by higher content of organic acids, which protect honey against microbial spoilage (Khalil et al. 2012). The ordinary concentration of organic acids in honeys is $0.5 \mathrm{~g} / 100 \mathrm{~g}$ (Antmann 2009). In our results the $\mathrm{pH}$ value of honey samples were between $3.23 \pm 0.02$, and 4.12 \pm 0.04 ; and the mean value was 3.56 , while the herb enriched honeys' $\mathrm{pH}$ ranged from $2.91 \pm 0.02$ to $4.12 \pm 0.4$, and the average value was 3.69. In case of herbhoneys the lowest $\mathrm{pH}$ was $3.76 \pm 0.01$ and the highest was $4.62 \pm 0.3$, the mean value was 4.07. Comparing our results with other studies it can be seen that very similar results were obtained by Juszczak et al. (2009). If we consider the mean of sample, the herbhoneys showed higher $\mathrm{pH}$ values than the honeys and honey products, and these differences were statistically verified, however there were no differences between the honeys and herb enriched honeys.

The electrical conductivity of honeys is related to the ash content (mineral content) and acidity, revealing the presence of ions, organic acids and 
proteins (Yücel and Sultanoglu 2013); thus their higher concentration means higher conductivity. Electrical conductivity depends on the raw material from which the honey was produced and this is a suitable parameter to determine the honey type (Kaškonienė et al. 2010). Codex Alimentarius Hungaricus appoints the honeys electrical conductivity in maximum $800 \mu \mathrm{S} \mathrm{cm}$. The examined samples showed lower values. The mean value was $278 \mu \mathrm{S} \mathrm{cm}^{-1}$ and the results have a wide range from $138 \pm 2 \mu \mathrm{S} \mathrm{cm}^{-1}$ to $585 \pm 4 \mu \mathrm{S} \mathrm{cm}^{-1}$. The results show that the electrical conductivity of herb enriched honey ranged between $168 \pm 4 \mu \mathrm{S} \mathrm{cm}^{-1}$ to $870 \pm 4 \mu \mathrm{S} \mathrm{cm}^{-1}$, however the mean value $\left(420 \mu \mathrm{S} \mathrm{cm}^{-1}\right)$ was higher. Last but not least the herbhoneys' electrical conductivity was between $448 \pm 4 \mu \mathrm{S} \mathrm{cm}^{-1}$ and $963 \pm 9 \mu \mathrm{S} \mathrm{cm}^{-1}$, and the average value was $643 \mu \mathrm{S} \mathrm{cm}$. In some case the solution exceeding the permitted value, however, the samples of herbhoneys were tested by Juszczak et al. (2009) and Dżugan et al. (2017), and they measured relatively high conductivity. The difference the between groups were statistically verified in every case.

Proline originates mainly from the salivary secretions of honeybees (Apis mellifera L.) during the conversion of nectar into honey. In honey, proline represents $50-85 \%$ of total amino acids (Iglesias et al. 2006, Truzzi et al. 2014). Currently there is no clear regulation on the proline content of honeys therefore, the minimum value of $180 \mathrm{mg} \mathrm{kg}^{-1}$, adopted in Germany, was taken as basic value. The proline content of honeys, herb enriched nectar honeys, and herbhoneys did not show significant differences. The lowest and highest values were measured in herb enriched nectar honeys (250 and $1187 \mathrm{mg} \mathrm{kg}^{-1}$ ) and the mean content was $640 \mathrm{mg} \mathrm{kg}^{-1}$. Honeys and herbhoneys showed similar results.

\section{CONCLUSION}

We concluded that the moisture content of herbhoneys was statistically justified lower than in the multifloral honeys and herb enriched honeys.

In case of $\mathrm{pH}$ value, we concluded that the multifloral honeys and herb enriched honeys had significantly lower $\mathrm{pH}$ value than herbhoneys.

In case of electrical conductivity, the multifloral honeys showed the lowest value followed by herb enriched honeys and herbhoneys. The differences between these groups were statistically verified.

Herb enriched honeys showed the highest proline content followed by multifloral honeys and herbhoneys, but there were no any statistically verified differences between these groups.

Based on our research, it can be concluded that the multifloral honeys and natural honeys enriched with herbs have very similar physicochemical properties; however, in many cases herbhoneys showed differences.

The electrical conductivity was the only one parameter, which showed statistically verified difference, so we can conclude that the herb honeys have the highest mineral content.

Every examined sample, including the herbhoneys, corresponded to the quality standards of honeys.

\section{REFERENCES}

Antmann M. (2009): Különleges fajtamezek botanikai eredetének és illó komponenseinek összefüggése. Budapest.

Bogdanov, S.-Martin, P.-Lüllman, C. (1997): Harmonised methodes of the European honey commission. Apidologie. 59.

Crane, E. (1983): The archaeology of beekeeping. Gerald Duckworth \& Co. Ltd. London.

Codex Alimentarius Hungaricus (2009): A Magyar Élelmiszerkönyv 1-190/496 számú előírása az élelmiszerek tápérték jelöléséről. „B part”.

Czipa N. (2010): Különböző eredetü mézek összehasonlító vizsgálata és a gyártmánykialakítás hatása a minőségre. Debrecen.

Downey, G.-Hussey, K.-Kelly, J. D.-Walshe, T. F.-Martin, P. G. (2005): Preliminary contribution to the characterisation of artisanal honey produced on the island of Ireland by palynological and physico-chemical data. Food Chemistry. 91. 2: 347-354.

Dżugan, M.-Sowa, P.-Kwaśniewska, M.-Wesołowska, M.Czernicka, M. (2017): Physicochemical Parameters and Antioxidant Activity of Bee Honey Enriched With Herbs. Plant Foods Hum. Nutr. 72: 74-81.

Iglesias, M. T.-Martian-Alvarez, P. J.-Polo, M. C.-Lorenzo, C.Gonzalez, M.-Pueyo, E. N. (2006): Changes in the free amino acid contents of honeys during storage at ambient temperature. Journal Agricultural and Food Chemistry. 54: 9099-9104.
Isadorov, V. A.-Bagan, R.-Bakier, S.-Swiecicka, I. (2015): Chemical composition and antimicrobial activity of Polish herbhoneys. Food Chem. 171: 84-88.

Jamróz, M. K.-Paradowska, K.-Zawada, K.-Makarova, K.Kaźmierski, S.-Wawer, I. (2014): 1H and 13C NMR-based sugar profiling with chemometric analysis and antioxidant activity of herbhoneys and honeys. J. Sci. Food Agric. 94: 246255.

Juszczak, L.-Socha, R.-Roznowski, J.-Fortuna-Nalepka, K. (2009): Physicochemical properties and quality parameters of herbhoneys. Food Chem. 113: 538-542.

Kaškonienè, V.-Venskutonis, P. R.-Čeksterytè, V. (2010): Carbohydrate composition and electrical conductivity of different origin honeys from Lithuania. LWT Food Sci. Technol. 43: 801-807.

Khalil, I.-Moniruzzaman, M.-Boukraâ, L.-Benhanifia, M.-Islam, A.-Islam, N.-Sulaiman, S. A.-Gan, S. H. (2012): Physicochemical and antioxidant properties of Algerian honey. Molecules. 17: 11199-11215.

Lukasiewicz, M.-Kowalski, S.-Makarewicz, M. (2015): Antimicrobial an antioxidant activity of selected Polish herbhoneys. Food Science and Technology. 64: 547-553.

MSZ 6943/3-80: Magyar Szabvány (198b). Méz kémiai és fizikai vizsgálata. Savfok és pH meghatározás. 
Meda, A.-Lamien, C. E.-Romito, M.-Millogo, J.-Nacoulma, O. G. (2005): Deremination of the total phenolic, favonoid and prolin contents in Bukina fasan honey, as well as their radicalscavering activity. Food Chem. 91: 571-577.

Nagy É.-Prokisch J.-Daróczi L.-Harangi J. (2014): A borsmenta hatóanyagai mézben. Élelmiszervizsgálati Közlemények. 60. 3: 294-300

Socha, R.-Juszczak, L.-Pietrzyk, S.-Fortuna, T. (2009): Antioxidant activity and phenolic composition of herbhoneys. Food Chem. 113: 568-574.
Szalay L. (2009): Gyógyméz? Méhészet. 57. 1: 12

Truzzi, C.-Annibaldi, A.-Illuminati, S.-Finale, C.-Scarponi, G. (2014): Determination of proline in honey: Comparison between official methods, optimization and validation of the analytical methodology. Food Chem. 150: 477-481.

Yücel, Y.-Sultanoglu, P. (2013): Characterization of honeys from Hatay region by their physicochemical properties combined with chemometrics. Food Bioscience. 1: 16-25. 